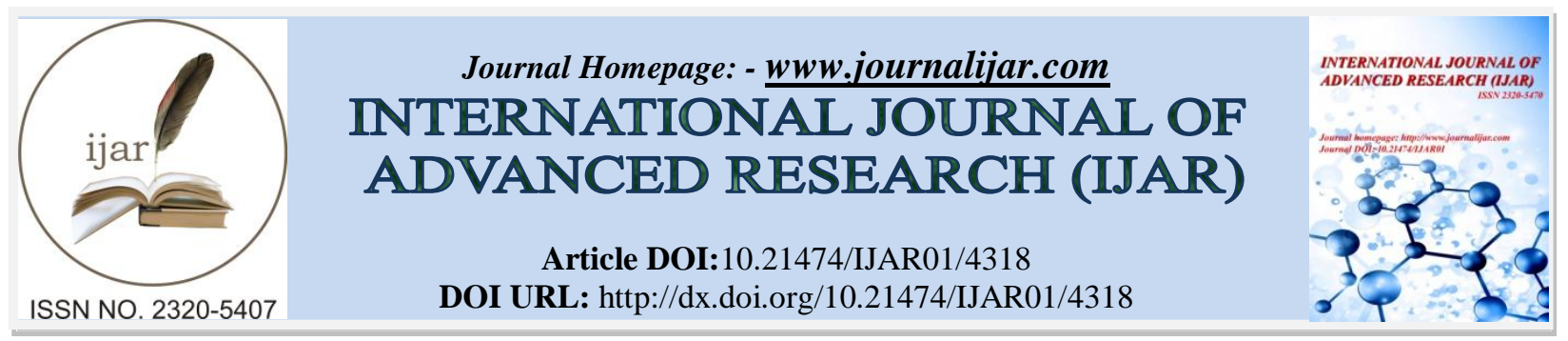

RESEARCH ARTICLE

\title{
LEGAL ASPECT OF ADMINISTRATIONOF DOCTOR AN UNLICENSED IN THE MEDICAL SERVICE.
}

Andi Nita Kurniawati Ramadhani.

Student at Graduate School of Hasanuddin University. Indonesia.

\section{Manuscript Info}

(.........................

Manuscript History

Received: 23 March 2017

Final Accepted: 28 April 2017

Published: May 2017

Key words:-

Practice License, Registration

Certificate, Legal Administration.

\section{Abstract}

Every doctor or dentist is required to have a practice license prior to practicing medicine in Indonesia. Doctors or dentists who perform medical practice prior to the Practice License constitute an act of violation of medical administration law and may be threatened with a fine.

Copy Right, IJAR, 2017,. All rights reserved.

\section{Introduction:-}

In the preamble of the Constitution of the State of the Republic of Indonesia Year 1945 explained that one of the goals of the state of Indonesia is to protect the entire nation of Indonesia and the entire Indonesian blood spill. To achieve these objectives the government seeks to maximally provide protection to all citizens in various areas of life. In addition to these objectives, the government is also obliged to carry out development in various fields in order to realize national welfare. In connection with this, the government issued Law No. 36 of 2009 on Health which is intended as an effort made by the government in order to carry out development in the field of health.

Provision of health services by doctors and / or hospitals to patients is not limited to the application of medical technology alone but must also be accompanied by the application of social values, culture, ethics, law and religion. It is already understood much earlier by leaders in the field of medicine with the Medical Profession Ethics drawn up in the form of the Code of Hammurabi and Code Of Hittiles but the most famous is the Hippocratic oath which contains obligations to behave and be a doctor or something like Code Of Conduct for doctors.

In such relationships, even if the patient is from a common person on health issues, doctors and hospitals should fulfill their obligation to provide health services according to service standards, professional standards, and operational standards of procedures to patients whether requested or unasked. Because the principle of the therapeutic transaction, the health provider and the receiver of health that are both legal subjects who have rights and obligations, ${ }^{1}$ in accordance with the legal principle of equality before the law.

To realize satisfactory health services to the community that provides legal protection, the government issued Law No. 29 of 2004 on Medical Practice. The law is expected to provide protection to the community, maintain and improve the quality of services, and provide legal certainty.

\footnotetext{
${ }^{1}$ Sampara, Said dkk., 2009, Buku Ajar Pengantar Ilmu Hukum, Yogyakarta, Total Media, p. 151
} 
From the principle or patient-physician (other health-care) relationship-the hospital, known as the therapeutic or therapeutic relationship, where there is a contractual (though unwritten) contract between the patient and the physician in terms of treatment and treatment of the illness and between Patients with hospitals in terms of health services by providing standardized facilities and infrastructure.

In such relationships, even if the patient is from a common person on health issues, doctors and hospitals should fulfill their obligation to provide health services according to service standards, professional standards, and operational standards of procedures to patients whether requested or unasked. Because the principle of the therapeutic transaction, the health provider and the receiver of health that are both legal subjects who have rights and obligations, in accordance with the legal principle of equality before the law.

In Law 29 of 2004 on Medical Practice, the definition of professional standards is mentioned in the explanation of article 50 as follows:

What is meant by professional standards is limit the ability (knowledge, skills and professional attitude) minimum that must be controlled by an individual to be able to perform professional activities in the community independently made by professional organizations.

The explanation of article 50, is an explanation and article $50 \mathrm{sub}$ a that states that doctors who perform medical practice in accordance with professional standards and operational standards procedures, are entitled to legal protection. Then in article $50 \mathrm{sub} \mathrm{b}$ is further mentioned that providing medical services according to professional standards and standard operational procedures is also the right of doctors.

And the article 50 sub a and $\mathrm{b}$ and the explanation mentioned above, it can be seen that the law requires in the implementation of medical practice, the doctor is entitled to carry out the practice in accordance with professional standards, and if it has implemented the practice according to the applicable professional standard, then he is entitled to legal protection.

And the professional standards described in the explanation of article 50, it can be described the following elements and professional standards:

1. Professional standard is the minimum ability limit for doctors.

2. These capabilities include:

a. knowledge (knowledge);

b. skills (skills);

c. professional attitude (professional conduct).

3. Ability consisting and 3 (three) elements, must be controlled by an individual (doctor who performs medical practice).

4. This ability is also a requirement to allow a doctor to conduct his or her professional activities on the community independently.

5. The right to make professional standards according to Medical Practice law is a professional organization. The current professional organization of physicians is the Indonesian Doctors Association (IDI), which, in terms of professional standards and individual specializations, may be submitted to each of the professional associations within the area of the specialization.

In addition to professional standards, the law also mentions the existence of standard operational procedures defined in the explanation of Article 50 of the Medical Practice Law as follows:

Standard operating procedures are a set of standardized instructions / steps to complete a certain routine work process.

The purpose of this standard operating procedure is to provide the right and best action based on mutual consensus to carry out various activities and service functions. Whereas the right to make standard procedure of service is health service facility, and its action still refers to or based on professional standard, or in other words standard of operational procedure should not be distorted and professional standard which has been determined by professional organization. 
It is very important to communicate well from the doctor or hospital about the patient's health problems in a complete and detailed manner so that the patient understands about his / her health condition and his / her rights as a patient who is also protected by law. Another advantageous thing with good communication is that the patient knows that to what extent is his health or the severity of his illness and the ability of the physician to assist his problem in accordance with the conditions at that time.

In order to provide protection and legal certainty to the public, doctors / dentists and specialist / dentist specialists, especially on disciplinary offenses unrelated to doctor-patient relationships need to be monitored and evaluated in sustainable medical practice.

But in recent years, doctors and / or hospitals' relationships with patients face challenges because some cases of complaints or allegations to doctors and / or hospitals have undertaken health efforts in health care or known as malpractice, often contained in media mass. Malpractice itself occurs not only in patients with a doctor but sometimes the patient to the hospital, it gives us that society as health receivers have now been demanding implementation of the rights that they have these, now they have to judge even criticized the quality of service The health they receive.

Lack of good communication between physicians and patients is the cause of many complaints of alleged disciplinary violations (the community calls them malpractice allegations) by doctors and dentists.

As a result even though the doctor has performed the task according to service standards, professional standards and standard operating procedures, but there are times when patients still feel harmed because the outcome of therapy is not as expected.

Until March 2016, the Indonesian Medical Disciplinary Council (MKDKI) has handled 166 complaints of disciplinary offenses committed by doctors or dentists. Of these, about 70 percent is due to a lack of communication between doctors and patients. In the details of the discipline, the most common are general practitioners (61 cases), surgeon (40 cases), obstetrician and obstetrician (11 cases), pediatrician (8 cases), internist ( 3 cases), anesthesiologist (10 cases), ophthalmologist (3 cases), cardiologist (3 cases), radiologist ( 2 cases), And each 1 case by psychiatrist, ENT expert and dermatologist and 10 dentists. Based on the source of the most complaints submitted by the community of 119 cases, followed by the Ministry of Health / Health Office 4 cases, health workers 2 cases and each 1 case of complaints from health care institutions and insurers. ${ }^{2}$

To realize the administrative order of doctors / dentists and specialist doctors / dentists specialists are required regulations related to administrative law enforcement.

In the Law No. 29 of 2004 said that the practice license is written evidence given by government to the doctor and dentist who will run the medical practice after meeting the requirements. ${ }^{3}$ In relation to the problem of malpractice, the licensing instruments regulated in state administrative law are related to the occurrence of administrative malpractice acts.

Every doctor / dentist and specialist / dentist specialist who performs medical practice must have a registration certificate and through an evaluation process that includes administrative evaluation and competency evaluation in accordance with applicable laws and regulations.

Therefore, the licensing instrument becomes one of the important factors when a doctor will open a health practitioner, because the licensing instrument can be used as evidence that the doctor concerned is competent to carry out his medical practice.

${ }^{2}$ http://www.depkes.go.id/article/print/1519/dugaan-pelanggaran-disiplinterbanyak-akibat-kurangnyakomunikasi-dokter-dan-pasien.html, Accessed on 22 November 2016.

${ }^{3}$ Article 1 of Law No. 29 of 2004 on Medical Practice 
For doctors / dentists and specialists / dentist who does not have a letter of registration and disciplinary offenses that are not related to the doctor-patient relationship, the Indonesian Medical Council can impose administrative sanctions in accordance with regulations. ${ }^{4}$

With the enforcement of administrative sanctions can ensure order and smooth implementation of duties and can encourage doctors / dentists and specialist / dentist specialist to be more productive and oriented on improving the quality of medical services and patient safety.

This research outlines as follows to explain: 1. Implementation of licensing practice of doctors in Makassar City in terms of administrative law. 2. Implementation of administrative sanctions against the violation of medical practice licenses in medical services.

\section{Methods of the Research:-}

The type of research used in this study is the method of legal juridical empirical research that is the method of research using materials derived from the legislation rules of related legal norms and related to the title of this study are interrelated and sustainable to each other in this research. In this case using literature data and field research.

From the results of libraries research and field research are conducted descriptive analytical discussion. Descriptive is the exposure of research results with the aim to obtain a comprehensive picture but still systematic especially about the facts related to the problems to be studied. Analytical means that the obtained image is carefully analyzed so that it can be known about the purpose of this research itself is to prove the problem as has been formulated in the formulation of the problem. The next stage is data processing that is the analysis conducted by qualitative method is "research method based on post philosophy Positivism, is used to examine the natural condition of the object, where the researcher is the key instrument, the data collection technique is done in triangulation, the data analysis is inductive / qualitative, and the qualitative research results emphasize the meaning of the generalization". 5

\section{Results and Discussion:-}

Reality Case Doctor Who Do not Have a License to Practice in the city of Makassar:-

Every doctor or dentist is required to have a practice license prior to practicing medicine in Indonesia. This doctor's duty was originally an administrative legal duty raised to criminal law because the violation of the obligation was punishable by the criminal. The threat of imprisonment against a doctor or dentist who does not have a letter of register (Article 75 paragraph (1)) and the threat of imprisonment against a doctor or dentist who does not have a license of practice (Article 76) But in connection with the hearing of the decision of the Court Constitution No. 04 / PUU-V / 2007 dated June 19, 2007 on the petition for the judicial review of Law Number 29 Year 2004 concerning Medical Practice, the criminal threat is abolished because it is not proportional or not proportional to the violation so that it is not in line with Article 28 G Paragraph (1) of the Constitution 1945. However, to doctors and dentists who do not have a letter of registration or do not have a license of practice, can still be threatened with a fine of fines.

In the last 5 years, the year 2011 to 2015 practitioner doctors in the data by the Indonesian Doctors Association (IDI) are as follows:

Table 1.1:- Number of Practice Doctors in Makassar City.

\begin{tabular}{|c|c|l|c|}
\hline No & Year & \multicolumn{1}{|c|}{ Doctor } & amount \\
\hline \multirow{2}{*}{1.} & \multirow{2}{*}{2011} & General practitioners & 104 \\
\cline { 3 - 4 } & & Dentist & 36 \\
\cline { 3 - 4 } & & Medical specialist & 486 \\
\hline \multicolumn{2}{|c|}{ amount } & $\mathbf{6 2 6}$ \\
\hline \multirow{2}{*}{2.} & General practitioners & 96 \\
\cline { 3 - 4 } & \multirow{2}{*}{2012} & Dentist & 44 \\
\cline { 3 - 4 } & & Medical specialist & 589 \\
\hline \multicolumn{2}{|c|}{} & amount & $\mathbf{7 2 9}$ \\
\hline 3. & 2013 & General practitioners & 110 \\
\hline
\end{tabular}

\footnotetext{
${ }^{4}$ A copy of the Indonesian Medical Council Regulation No. 43 of 2016

${ }^{5}$ Sugiyono, Metode Penelitian Kuantitatif, Kualitatif, dan R \& D, Alfabeta, Bandung, 2012, p. 9
} 


\begin{tabular}{|l|l|l|c|}
\hline \multirow{2}{*}{} & Dentist & 69 \\
\cline { 3 - 4 } & Medical specialist & 719 \\
\hline \multicolumn{2}{|c|}{ amount } & $\mathbf{8 9 8}$ \\
\hline \multirow{2}{*}{4.} & General practitioners & 132 \\
\cline { 3 - 4 } & \multirow{2}{*}{2014} & Dentist & 75 \\
\cline { 3 - 4 } & Medical specialist & 788 \\
\hline \multirow{2}{*}{5.} & amount & $\mathbf{9 9 5}$ \\
\hline \multirow{2}{*}{2015} & General practitioners & 148 \\
\cline { 3 - 4 } & & Dentist & 72 \\
\cline { 3 - 4 } & Medical specialist & 801 \\
\hline \multicolumn{2}{|c|}{ amount } & $\mathbf{1 0 2 1}$ \\
\hline \multicolumn{2}{|c|}{ Total } & 4269 \\
\hline
\end{tabular}

(Source: Secondary Data, processed in 2015)

Table 1.2:- Administrative Offenses

\begin{tabular}{|l|l|}
\hline No. & Breach Practice Doctor Viewed from Aspect Administration \\
\hline 1. & Does not have a Registration Certificate (STR) and Practice License (SIP). \\
\hline 2. & The expiration of Registration Certificate (STR) and Practice License (SIP) \\
\hline 3. & Not making medical records when practicing medicine. \\
\hline
\end{tabular}

In the last 5 years, the year 2011 to 2015 practitioner doctors in the data by the Health Office of Makassar are as follows:

Table 1.3:- Number of Practice Doctors in Makassar City

\begin{tabular}{|c|c|c|c|c|c|}
\hline \multirow[t]{2}{*}{ No } & \multirow[t]{2}{*}{ Year } & \multirow[t]{2}{*}{ Doctor } & \multicolumn{2}{|c|}{ Without permission } & \multirow[t]{2}{*}{ Has Permission } \\
\hline & & & $\begin{array}{c}\text { Not Own } \\
\text { Permission }\end{array}$ & Is not valid & \\
\hline \multirow[t]{3}{*}{1.} & \multirow[t]{3}{*}{2011} & $\begin{array}{l}\text { General } \\
\text { practitioners }\end{array}$ & 21 & 16 & 67 \\
\hline & & Dentist & 11 & 5 & 20 \\
\hline & & Medical specialist & 10 & 9 & 467 \\
\hline \multicolumn{3}{|c|}{ amount } & 42 & 30 & 554 \\
\hline \multirow[t]{3}{*}{2.} & \multirow[t]{3}{*}{2012} & $\begin{array}{l}\text { General } \\
\text { practitioners }\end{array}$ & 20 & 9 & 67 \\
\hline & & Dentist & 11 & 5 & 28 \\
\hline & & Medical specialist & 12 & 7 & 570 \\
\hline \multicolumn{3}{|c|}{ amount } & 43 & 21 & 665 \\
\hline \multirow[t]{3}{*}{3.} & \multirow[t]{3}{*}{2013} & $\begin{array}{l}\text { General } \\
\text { practitioners }\end{array}$ & 28 & 11 & 71 \\
\hline & & Dentist & 8 & 4 & 57 \\
\hline & & Medical specialist & 12 & 7 & 700 \\
\hline \multicolumn{3}{|c|}{ amount } & 48. & 22 & 828 \\
\hline \multirow[t]{3}{*}{4.} & \multirow[t]{3}{*}{2014} & $\begin{array}{l}\text { General } \\
\text { practitioners }\end{array}$ & 39 & 13 & 80 \\
\hline & & Dentist & 7 & 3 & 65 \\
\hline & & Medical specialist & 8 & 4 & 776 \\
\hline \multicolumn{3}{|c|}{ amount } & 54 & 20 & 921 \\
\hline \multirow[t]{3}{*}{5.} & \multirow[t]{3}{*}{2015} & $\begin{array}{l}\text { General } \\
\text { practitioners }\end{array}$ & 19 & 7 & 122 \\
\hline & & Dentist & 7 & 4 & 61 \\
\hline & & Medical specialist & 12 & 5 & 784 \\
\hline \multicolumn{3}{|c|}{ amount } & 38 & 16 & 967 \\
\hline
\end{tabular}




\begin{tabular}{|c|c|c|c|}
\hline Total & $\mathbf{2 2 5}$ & $\mathbf{1 0 9}$ & $\mathbf{3 9 3 5}$ \\
\hline \multicolumn{3}{|c|}{ (Source: Secondary data, processed in 2015) } \\
\hline
\end{tabular}

If seen from the table above, then the doctor who practiced without the permission of good practice of general practitioners, dentists, and specialists from year to year have fluctuated. Viewed from the year 2011 doctors who recorded do not have a license of practice amounted to 42 doctors, while the validity period of the license has been depleted amounted to 30 doctors. In 2012 doctors who do not have a license to practice amounted to 43 doctors, while the license period has expired amounted to 21. In 2013 to September, doctors who do not have a license for practice amounted to 48 doctors, and the validity period of the license has been Out of 22 doctors. In the year 2014 doctors who do not have a license for practice amounted to 54, and the validity period of the license has been exhausted amounted to 20. And In 2015 doctors who do not have a license of practice amounted to 38, and the validity period of the license has expired amounted to 16.

Table 1.4 :- Factors Affecting Doctors Perform Unlicensed Practices.

\begin{tabular}{|l|l|l|}
\hline No. & Not Have License & License is Not Applicable \\
\hline 1. & $\begin{array}{l}\text { Have not received recommendation from IDI } \\
\text { Professional Organization }\end{array}$ & Expired STR and SIP \\
\hline 2. & Have not passed the Competency Test Doctor & \\
\hline 3. & Do not have STR and SIP yet & \\
\hline
\end{tabular}

Based on the above description of the factors affecting Doctors performing Unlicensed Practices, can be described as follows:

Not Have License:-

Have not got the recommendation of IDI Profession Organization.

If a doctor is not a member of the IDI Professional Organization, then the doctor can not obtain a recommendation from the Chairman of the IDI where the recommendation will be used as a condition to complete the management of STR.

Have not passed the competency test:-

After graduating from medical examination, a doctor must follow and pass the competency test. Where the results of this competency test is also used as one of the requirements in completing the management of STR.

\section{Do not have STR:-}

In the management of the STR, a physician must complete the requirements - requirements such as; Must pass the competency test and or get a recommendation from the IDI Professional Organization. If a doctor does not have a STR then directly in the management of Practice License (SIP) will also be hampered.

License is Not Applicable.

Not to extend STR and SIP:-

SIP remains valid for the STR is still valid as well. In extending SIP a doctor must first extend his STR. Most of the doctors have not extended the STR because they have not met the requirements that have been determined or because SKP (Participation Credit Unit) is still lacking.

\section{The Doctor's requirements permission document, among others:-}

1. Photocopy of ID card;

2. Photocopy of diploma certified by the University for new SIP applicants;

3. Appointment Letter (CPNS / PNS / PTT) for Medical Personnel having status as Civil Servant and Non Permanent Employee (PTT);

4. Photocopy of Registration Certificate (STR) issued and legalized original by Indonesian Medical Council (KKI);

5. Statements have a place of practice or certificate from the Director / Responsible health service facility as a place of practice;

6. Letter of approval from the immediate supervisor for Medical Personnel working in government health service institutions / facilities or at other health service institutions / institutions in full time; 
7. Letter of statement from the Head of the Health Service / Authorized Officer for Medical Personnel who has obtained a practice place outside Makassar City;

8. Recommendation Letter of Professional Organization IDI / PDGI;

9. Letter of Recommendation from the Head of the local Puskesmas;

10. Health Certificate from doctor who obtained SIP;

11. Letter of statement willing to do visitation docked practice place

12. Attach a long Practice License (SIP) to those who will extend SIP;

13. Two $4 \times 6$ color photographs of 2 pieces and $3 \times 4$ size of 1 sheet;

The impact that can be caused if the medical practice without STR or SIP is causing adverse consequences of physical or mental health or the lives of the patient there is malpractice of medicine, although the medical practice is not contrary to professional standards and procedures and done on informed consent. Informed Consent is a consent or consent of a patient given as a consent or rational consent of a patient who is given freely, consciously and rationally, after he has obtained the information he or she understands from the doctor about his illness.

From violation of administrative legal obligations to criminal acts can be seen the intent of the legislators forming this crime, namely as a preventive effort to prevent doctors or dentists from malpractice medicine. As well as preventive efforts in order to avoid any casualties due to medical malpractice.

In Makassar City the doctor's case of unauthorized practice is directly handled by the Health Department and Profession Organization of IDI of Makassar City, because in cases that only include malpractice of ethics, the doctor will not be handled by the court, but simply by MKEK (Ethical Honorary Council of Medicine ). Where is MKEK who will give him sanctions. Where if MKEK can not tackle this case, it will be forwarded to P3EK (Committee on Consideration and Development of Medical Ethics). The police in this case will help mediate the doctors who are trapped in the crime, and coordinate and cooperate with the Health Office in regulation, licensing, and competence.

Obstacles or Difficulties that Occurred in the Enforce against Doctors Who Do not Have Practice License by the Health Service of Makassar City and the Indonesian Doctors Association Makassar City.

In the implementation of the prosecution of Doctors who do not have a Practice License there are obstacles that are quite inhibiting.

1. The doctor concerned ignores the coaching of the Professional Organization.

2. Clashing time.

3. Doctors are less responsive about the explanation of the doctor's practice permit rules.

4. Not meeting the Mediation call. .

5. Doctors are not in the practice place when BINWASDAL is implemented.

6. The doctor is not or has not been a member of professional organization IDI.

7. Doctors still running the practice of hidden.

Efforts to Enforce Against Doctors Who Do not Have Practice License by Health Office of Makassar City and Ikatan Dokter Indonesia Makassar City.

The number of practicing practitioners without having a Practice License in Makassar City resulted in the absence of legal certainty for healthcare users. Makassar City Health Office as a regional government work unit that regulates quality health service standards and the Indonesian Doctors Association Makassar City as a professional organization that oversees its members to run the code of medical ethics well, it has a big role in cracking down doctors who do not have a letter The Practice License.

Based on the research, the field data obtained regarding the action against doctors who do not have a license of practice are as follows:

1. Guidance and Mediation by IDI Professional Organization.

The guidance is carried out by the IDI Professional Organization to provide a detailed explanation of the doctor's practice regulation, whereas meditation is to unlock the contents of the mind and reflect on the importance of a practice license for a physician, and to give an understanding that practicing without permission is a violation of state law Resulting in the heaviest sanctions in the future.

2. Internal guidance by the Health Office.

In addition to coaching conducted by the IDI Professional Organization, Makassar City Health Office also provides personal guidance on the doctor's licensing rules to be obeyed and understood.

3. Verbal and written reprimands by the Health Office. 
a. Verbal reprimands.

Verbal reprimands are submitted to a Doctor who is not licensed by a period of 1 to 2 weeks to apply for the license.

b. Written warning.

Written warning is given to a Doctor for ignoring oral warning with a specified time limit.

This oral or written warning is one form of administrative sanction by the Health Office of Makassar City.

4. Coaching, Supervision and Control (BINWASDAL) to the place of Practice.

BINWASDAL is conducted by the Health Office team to monitor, monitor and provide guidance and control over the implementation of the practice license. BINWASDAL is part of the program implemented by the Health Office of Makassar City conducted periodically by BINWASDAL team, through:

a. Meeting and coordination with communication forums of professional organizations.

b. Field visits and supervision.

5. The Profession Organization does not provide recommendations to complete SIP.

Recommendation from professional organization of IDI is one of the requirements to complete SIP management, in other words if professional organization of IDI does not give recommendation hence the handling of doctor's license is delayed as long as professional organization of IDI has not give recommendation. In other words, the IDI Professional Organization has sanctioned the practicing physician without having a license of practice in accordance with the provisions of Article 38 paragraph 1 of the Law of the Republic of Indonesia Number 29 of 2004 on Medical Practice.

6. Permission revocation and closing of the practice.

A doctor is prohibited from carrying out health service activities as long as he / she does not have a license to practice. The health office has sought to impose sanctions on practicing physicians without having the license of practice in accordance with Regulation of the Minister of Health No. 2052 / MENKES / PER / X / 2011 on Practice License and Implementation of Medical Practice.

7. Revocation of Recommendations by IDI Professional Organization.

Removed its recommendations provided by professional organizations of IDI through a special session. As well as the revocation of these sanctions practice licenses are granted in accordance with Regulation of the Minister of Health of the Republic of Indonesia No. 2052 / MENKES / PER / X / 2011 concerning Practice License and Implementation of Medical Practice.

The crime of medical practice without a Practice License (SIP), basically stems from a violation of medical administration law. Violation of medical administration law that is given a criminal threat. Thus, the unlawful nature of the act in the offense lies in violation of administrative law

When viewed from the theory of law enforcement in terms of cultural factors, should be in the criminal law should prioritize the value of order rather than the value of tranquility. However, judging from the reality of the existing case, the value of tranquility that is preferred from the value of order, it has become a legal culture in Makassar in this case. Due to the legal culture that existed in the city of Makassar as described above, of course this is also related to the next factor of law enforcement factors. Where law enforcement officers can not be firm in taking action against practicing physicians without having a license of practice. Law enforcement officers can only mediate to a practicing doctor without a license of practice and coordinate with the health authorities or professional organizations rather than enforcing the law in criminal penalties. Where law enforcement efforts should provide a deterrent effect for doctors who practice without having a license of practice.

\section{Conclusion:-}

From the results of the Research, it is very clear that doctors / dentists and specialist doctors before practice should pay attention to administrative requirements before doing medical practice. Doctors should perform his duties in accordance with the Hippocratic oath which contains obligations to behave and be a doctor or something like Code Of Conduct for doctors. In the Medical Practice Law it is clear that doctors can not practice without STR and are followed by SIP. If you do not have, it is clear that you will be given sanctions according to the Medical Practice Law. 


\section{References:-}

1. Ameln,Fred, 1991, Kapita Selekta Hukum Kedokteran. Grafikatama Jaya, Jakarta.

2. Anny Isfandyarie, 2006. Tanggung Jawab Hukum dan Sanksi Bagi Dokter. Buku I. Prestasi Pustaka, Jakarta.

3. Daldiyono, 2007. Pasien Pintar \& Dokter Bijak. PT Bhuana Ilmu Populer, Jakarta.

4. Dalmy Iskandar, 1988. Rumah Sakit, Tenaga Kesehatan, dan Pasien. Penerbit Sinar Grafika, Jakarta

5. E. Utrecht, 1986. Pengantar Hukum Administrasi Indonesia. Pustaka Tinta Mas, Surabaya.

6. Handar Subhandi. Implementation of the National Health Insurance Scheme in the Public Health Center in Palopo City In Indonesia. Journal of Health, Medicine and Nursing. Vol.34. 2017.

7. Handar Subhandi. Legal Aspect Of Environmental Health On Sanitation Hygiene Of Refill Drinking Water Depot. International Journal of Advanced Research. Vol. 5 Issue (2). 2017.

8. Harupermadi.lecture.ub.ac.id, HaruPermadi, Mengenal Sanksi dalam Hukum Administrasi Negara.

9. Herbani Pasolong, 2007,Teori Administrasi Publik, Bandung; Alfabeta.

10. Hermien Hadijati Koeswadji, 1984. Hukum dan Masalah Medik. Airlangga University Press, Surabaya.

11. J. Guwandi, 1994. Kelalaian Medik (Medical Negligence). Balai Penerbit Fakultas Kedokteran Universitas Indonesia. Jakarta

12. J. Guwandi, 2007.Medical Law (Hukum Medik), Jakarta, Balai Penerbit FKUI.

13. J. Guwandi, 2007.Medical Error dan Hukum Medis, Jakarta, Balai Penerbit FKUI.

14. Kementerian Kesehatan Republik Indonesia, 2012. Pedoman Sistem Informasi Kesehatan, Jakarta.

15. Marshall Edward Dimmock, Gladys Ogden Dimmock, 1978. Administrasi Negara, diterjemahkan oleh Husni Tamrin Pane. Aksara Baru, Jakarta.

16. N.M. Spelt dan J.B.J.M. Ten Berge 1993. Pengantar Hukum Perizinan, disunting oleh Phillipus M. Hadjon. Yuridika, Surabaya.

17. Petunjuk Teknis Praktik Kedokteran, 2005. CV. Eka Jaya, Jakarta.

18. Phillipus M. Hadjon, dkk, 2002. Pengantar Hukum Administrasi Indonesia. Gadjah Mada Press University, Yogyakarta.

19. Ridwan H.R., 2006. Hukum Administrasi Negara. Raja Grafindo Persada, Jakarta.

20. Safitri Haryani, 2005. Sengketa Medik, Alternatif Penyelesaian Perselisihan Antara Dokter dengan Pasien. Diadit Media, Jakarta.

21. Sampara, Said dkk., 2009. Buku Ajar Pengantar Ilmu Hukum. Total Media, Yogyakarta.

22. Salinan Peraturan Konsil Kedokteran Indonesia Nomor 43 Tahun 2016

23. Satjipto Raharjo. 2007. Membangun Polisi Sipil, Perspektif Hukum, Sosial dan Kemasyarakatan, Jakarta.

24. Soerjono Soekanto, 2004. Faktor yang Mempengaruhi Penegakan Hukum. Jakarta.

25. Sri Mamudji.et.el., 2005. Metode Penelitian dan Penulisan Hukum. Fakultas Hukum Universitas Indonesia, Jakarta.

26. Sugiyono, 2006. Metode Penelitian Administrasi. Alfabeta, Jakarta.

27. Suryadhimirta, Rinanto, 2011. Hukum Malpraktik Kedokteran. Total Media, Yogyakarta.

28. Syafi'l. Ibnu Kencana, 1993. Ilmu Administrasi Publik. Rineka Cipta, Jakarta. 